\title{
The factors that influence audit quality by earnings surprise benchmark
}

\author{
Vina Aqmarina, Reni Yendrawati* \\ Accounting Department, Universitas Islam Indonesia, Yogyakarta, Indonesia \\ *Corresponding Author e-mail: reni.yendrawati@uii.ac.id
}

A R T I C LE INFO

Article history:

Available online

Keywords:

audit quality, audit tenure, auditor

rotation, age of publication,

earnings surprise benchmark

DOI:

https://doi.org/10.20885/jaai.vol23.

$\underline{\text { iss 1.art3 }}$

\section{A B S T R A C T}

This study is aimed at analyzing the influence of audit tenure, auditor rotation and age of publication on audit quality. Audit quality is gauged by earnings surprise benchmark. The population in this study is all of manufacturing companies listed on the Indonesia Stock Exchange in the period 2014-2017. Purposive sampling method was employed in this research study to gain the research sample. Then the technique of logistic regression was employed for data analysis. The research findings reveal that audit tenure and auditor rotation have a positive effect on audit quality, while age of publication has a negative effect on audit quality. The implication of this study is that financial statements users should not only focus on high or low profits, but also assess the quality of the audited financial statement.

\section{Introduction}

Financial statements provide information that have value in terms of assisting users, both external (such as investors, creditors) and internal parties, in decision making. In another hand, management produce financial statements as a form of responsibility in reporting the results of operational activities and financial position of the company. In the reporting, information gap is likely to occur resulted from different interests between management and users of the financial statements. As such, the role third parties is critical to examine the financial statements. In this respect, a public accountant is an appropriate professional as the third party, as it plays a significant role as auditor to carry out examination function on financial statements. Role of an auditor is of great importance in terms of assisting stockholders and other interested users to assess and investigate an organization's financial information, which in turn ensuring if the organization has truly referred to the accounting standards (Intakhan \& Ussahawanitchakit, 2010).

Auditing financial statements is expected to reduce information asymmetry that occurs between managers and users, and to assist in decision making process. The auditing process is designed in such a way that the results reported in financial statements show the company's activities and financial positions for real (Al-Thuneibat et al. 2011).

Numerous studies in Indonesia have examined audit quality, but very few have been found to use earnings surprise benchmark - a proxy employed to assess audit quality which emphasizes on profit quality (Suciana \& Setiawan, 2018). Herianti and Suryani (2016) conducted a study regarding audit quality by modifying measurements that had been adjusted to the conditions in Indonesia. This research was done by comparing the value of return of assets to its average range and standard deviation in the same period and industry. Thus, an auditor is expected to be able to uncover and report if management conduct profit management in preparing financial statements.

Based on prior studies, this research study aims to find out the influence of audit tenure, auditor rotation, and age of publication on audit quality in Indonesia's manufacturing companies in the period 2014-2017.

\section{Literature Review}

\section{Agency Theory}

According to Anthony and Govindarajan (2007), agency theory is the relation or contract between principal and agent. Agency theory assumes that each individual is motivated by his/her own interest that it gives rise to conflict of interest between principal and agent. The conflict of interest can be solved through an independent third party (mediator) between principal and agent. The third party will monitor the agent' behavior and ensure that the agent 
acts on behalf of the principal's interest. This third party which is independent is called external auditor, who will audit an organization' financial statements which in turn prove if the trust given to the agent is used on behalf of the agent or not.

\section{Stakeholders Theory}

In general, stakeholder is divided into two groups - primary and secondary groups. Primary group consists of capital owners or shareholders, creditors, employees, suppliers, consumers, distributors, and competitors or colleagues, while secondary group consists of local government, foreign government, social groups, mass media, supporting groups, society in general, and local people. The most important group to consider is the primary group because the success or failure of a company's business is largely determined by the mutually beneficial relationships created within the group. Therefore, the success and sustainability of a company's business should not harm any of the stakeholders in the primary group. To put it another way, the company must create a good, ethical and mutually beneficial relationship with the group, be honest, responsible for offering goods and services, and be fair. Stakeholder groups are taken into consideration by companies to disclose and / or not disclose information in financial statements (Ulum et al., 2008). To provide a performance accountability to the interested parties, an external auditor who has high independence and objectivity in assessing a financial report on the company is highly needed. It aims to ensure the accountability and reliability of financial statements.

\section{Earnings Surprise Benchmark}

Earnings surprise benchmark is a proxy to assess audit quality. In measuring audit quality, Herianti and Suryani (2016) modified measurements that had been adjusted to the conditions in Indonesia by comparing assets to its average range and standard deviation in the same period and industry.

The use of earnings surprise benchmark emphasizes on profit quality. It is well known that agent prefers financial statements that show high profits, so that principal will be satisfied with the agents' job performance. This may lead to information asymmetry in the financial statements. By emphasizing profit quality on earnings surprise benchmark approach, it is expected that an auditor can uncover and report if there is profit management by the management when preparing financial statements. Thus, an auditor should be able to provide financial statement information for real to organizations and able to assist the organizations in the decision-making process for avoiding possible losses to occur in the future.

\section{Audit Quality}

Audit quality is the likelihood of an auditor to uncover violations in financial statements produced by client companies, and the extent to which the audit's ability to uncover the frauds. Audit process aims to improve quality in the process of financial reporting prepared by management by means of high objectivity and independence of the auditor. In other words, to yield the increased quality financial statements, audit quality should be improved.

In relation to auditor's job, an auditor is required to assert an opinion on the fairness of financial statements in the form of quality audit report by maintaining independency and improving competence, the auditor's competence to uncover frauds or violations (Bawono \& Singgih, 2010). When an auditor has succeeded in revealing a material misrepresentation, it indicates that the auditor independence is good. Thus, the audit quality is also good. However, if an auditor has failed in reporting the material misrepresentation, the auditor independence is said to be poor, that the auditor cannot produce quality audit report, which in turn inhibits audit quality improvement.

\section{Audit Tenure}

Tenure is a term of audit engagement between a Public Accounting Firm and its client. Audit tenure is usually associated with its influence on auditor independence. A long-term relationship between Public Accounting Firm and its clients potentially induces proximity between the firm's colleagues and clients, which in turn impede auditor independence and reduce audit quality (Al-Thuneibat et al., 2011). This contrasts with Nugrahanti and Darsono, 2014) who stated in their research that within a short tenure in which an auditor has just engaged with a new client, extra time is needed for the auditor in order to be able to understand the client and the business environment. A brief tenure may induce limited acquisition of information (data and evidences). If there is incorrect data or the data is eliminated on purpose by managers, the data will be hardly found.

The explanation implies that the limitation of audit tenure is still under debate. Some say that if a Public Accounting Firm has a long-term engagement, it is more likely to create potential proximity between the Firm's colleagues and the client. However, if it is too short, the acquisition of business information on the client will be limited. 


\section{Audit Rotation}

To enhance auditor independence, audit rotation is carried out for the purpose of reducing proximity between the client and the auditor that audit the client company. According to Pramaswardana and Astika (2015), audit rotation is auditor turnover in a Public Accounting Firm to provide audit service to clients. Audit rotation aims to prevent potential proximity between client and auditor caused by long-term relationship. Rotation by Public Accountant (PA) is expected to provide a new point of view for the auditor, that audit can be carried out in an objective way.

The government regulation of the Republic of Indonesia has applied the PA rotation policy by issuing the government regulation No. 20/2015 Article 11 regarding Practices of Public Accountants containing the provision of audit services on historical financial information as referred to in Article 10 paragraph (1) letter a of an entity by a Public Accountant is limited to a maximum period of 5 (five) consecutive years.

\section{Age of Publication}

Age of publication is the age of an entity starting from its initial registration on the Indonesia Stock Exchange (IDX) or the beginning of selling its shares on the Stock Exchange until its viability is seen today. The longer the company's age is published on IDX, then the company is considered to have good financial statements quality and good management. One of the factors that make an auditor is facilitated in doing an audit is the length of producing financial statements by management, since the long duration is considered capable of doing financial management in an effective and efficient way.

A quality manager obviously has numerous experiences, primarily in the area of internal control (Fernando et al., 2010). The shorter the age of financial statements is published, then management is considered to produce less quality financial statements. It is because the management is not able to provide accurate information for users and does not have any ample experience in the area of internal control. Therefore, it is important that an auditor audit financial statements well accordance with the existing condition. With good audit quality, a company then will be a going-concern.

\section{The Influence of Audit Tenure on Audit Quality}

Audit tenure is a term of audit pact between a Public Accounting Firm and its client company. According to Nugrahanti and Darsono (2014), when an auditor is engaged with a new client, additional time is required to understand more the client and the environment. Thus, a relatively short audit tenure may lead to negative impacts, one of which is the acquired information is inadequate. In addition, if the error data is found or the data is eliminated on purpose by the manager(s), the data will be hardly found by the auditor. The last impact is, a relatively short audit tenure indicates insufficient knowledge of the client company, which in turn lead to reduced audit quality.

Studies by Ardani (2017) and Nugrahanti and Darsono (2014) proved that audit tenure has a positive influence on audit quality. It indicates that long-term audit tenure can increase the Public Accounting Firm's knowledge of its client company's condition, that the auditor can design an effective audit program and create quality financial statements. Based on this premise, hypothesis 1 is proposed as follows:

$\mathrm{H}_{1}$ : Audit tenure has a positive influence on audit quality

\section{The Influence of Audit Rotation on Audit Quality}

The regulations that control audit rotation aims to restrict the length the audit engagement period that can increase the independence of an auditor. Thus, any policy concerning audit rotation is expected to prevent and diminish the close relationship with auditors. Therefore, an organization must change its auditor by using another public accounting firm for the sake of objectivity. If auditor change is not performed, it is likely that the auditor independence is threatened.

According to Velte and Stiglbauer (2012), by performing audit rotation, an auditor will be likely to improve quality. It is in line with Siregar et al. (2012) who stated that the regulation of audit rotation is made for the purpose of enhancing quality. The statements are based on the assumption that the longer the relationship between the auditor and client, the weaker the auditor independence. This premise is corroborated by studies of Kurniasih and Rohman (2014) revealing that audit rotation has a positive influence on audit quality. Based on the theories and prior research findings, hypothesis 2 is proposed as follows:

$\mathrm{H}_{2}$ : Audit rotation has a positive influence on audit quality 


\section{The Influence of Publication Age on Audit Quality}

Companies that have long been listed on the stock exchange show that they still exist and are able to survive. Longterm publication on the stock exchange is considered to have good quality in many aspects - management and operations, etc. For example, a manager who can provide clear information obviously facilitate the work of an auditor to perform an audit - such as detecting fraud if any, due to information availability.

Paramita and Latrini (2015) contended the same thing, longer age of publication can reduce criminal acts committed by management due to decreased level of discretionary accrual on a company. This makes an auditor able to quickly detect errors or mistakes in financial statements. Thus, hypothesis 3 is proposed:

$\mathrm{H}_{3}$ : Age of publication has a positive effect on audit quality.

\section{Research Model}

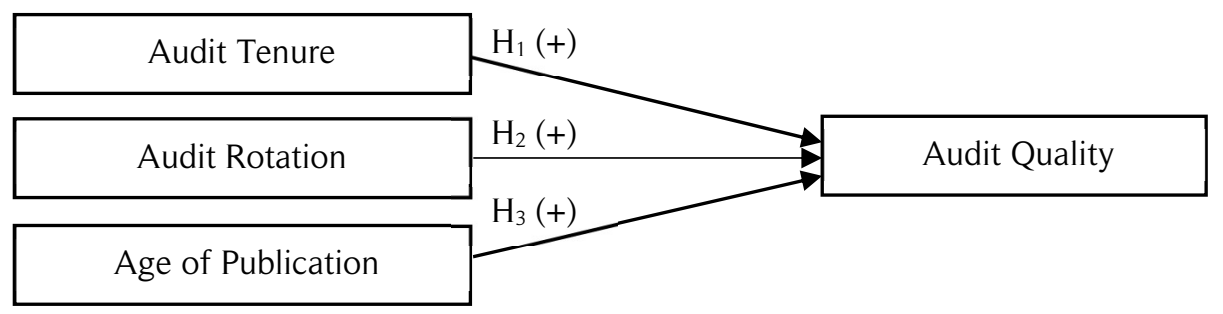

Figure 1. Research Model

\section{Research Method}

\section{Population and Sample}

The population in this research study is manufacturers listed on Indonesia Stock Exchange (IDX) in the period 2014 - 2017 and the sample is 148 manufacturers. Determining the sample design is based on a purposive sampling method. Out of the 148 manufacturers, 9 manufacturers did not publish their financial statements, 5 manufacturers did not include names of their Public Accounting Firms and auditors in their audited financial statements, 30 manufacturers used a currency other than Rupiah, 4 manufacturers were delisted from the Stock Exchange, 2 manufacturers performed sector switching, and 41 manufacturers had a negative value of Return of Asset and their age of publication was under 2 years. Thus, the research sample is 57 manufacturers that have met the criteria; the number is multiplied with the four-consecutive year-observation term. So, 228 samples are obtained.

\section{Data Collection Method}

The data in this research is financial statements of manufacturing companies, taken from the official website of Indonesia Stock Exchange, and the official website of the companies in the period 2014-2017. The data was gathered by technique of document observation by studying the financial statements of the sample companies.

\section{Dependent Variable}

The dependent variable in this research is audit quality, analyzed by proxy of earnings surprise benchmark. Audit quality $(\mathrm{Y})$ is the likelihood of an auditor to discover and report misrepresentation in independent audit reports according to the given criteria. In the current research, earnings surprise benchmark is the proxy of audit quality, to detect and uncover profit management committed by management for the purpose of avoiding reporting losses. According to Suciana and Setiawan (2018), audit quality is categorized into two:

1. Audit quality is high (MEET_BE=1) if the profit value falls in the range of normal value.

2. Audit quality is low (MEET_BE=0) if the profit value falls outside the range of normal value. The audit quality is assumed to be low, if:

a. The profit exceeds earning benchmark, namely the value of ROA $>\mu+\sigma$

b. The loss exceeds earning benchmark, namely the value of $\mathrm{ROA}<\mu+\sigma$

To measure audit quality, ROA formula is then used by means of checking if ROA falls in the benchmark or not. If it does $(\mu-\sigma<\operatorname{ROA}<\mu+\sigma)$, it indicates that the audit quality is good. Otherwise, if ROA falls outside benchmark $(\operatorname{ROA}>\mu+\sigma)$ or $(\operatorname{ROA}<\mu+\sigma)$, it indicates the audit quality is poor. The explanation is, $\mu$ is the ROA average of the entire research sample and $\sigma$ is its deviation. The more the Public Accounting Firm can produce 
good audit quality, the more the clients put trust on the audit service. For good audit quality, value of 1 is given, while for poor audit quality, 0 is given. This variable is symbolized with KA.

\section{Independent Variable}

\section{Audit tenure}

Audit tenure is a term of audit engagement of an auditor who provides an audit service with a period agreed with the client. According to Junaidi and Hartono (2010), audit tenure is the duration of the auditor-client relationship measured by the amount of years. The audit tenure in this research study refers to the research by Herianti and Suryani (2016) that is by using interval scale accordance with the duration of the relationship between the auditor and the company.

Audit tenure is gauged by counting the number of engagement years in which the same Public Accounting Firm has an audit engagement with a client company. The first engagement year in this research is 2014, by using number 1 and is added with one (1) for subsequent years during the year span of observation, which is 2014-2017. This information is seen in an independent audit report for a few years to reveal the length of the PAF's auditor who audits a company.

Audit rotation

Audit rotation is auditor turnover in a Public Accounting Firm to provide audit service to clients. In this research study, rotation is gauged using dummy variable. Value of 1 is given, if the client company performed an auditor rotation from the previous year in the research period 2014-2017. Value of 0 is given, if the company did not perform an auditor rotation.

Age of Publication

Age of publication is the age of an entity starting from its initial registration on the Indonesia Stock Exchange (IDX) or from its Initial Public Offering (IPO) - the first time the company sells its shares to the public until the observation year. Age of publication is measured by counting the entity's age since its initial registration on the IDX to the period of research observation year, that is 2017.

\section{Data Analysis Method}

Hypotheses testing was conducted using logistic regression analysis. The regression equation employed in this research is as follows.

$$
\mathrm{KA}=\alpha+\beta_{1} \mathrm{AT}+\beta_{2} \mathrm{RA}+\beta_{3} \mathrm{UP}+\varepsilon_{\mathrm{i}}
$$

Information:

$\mathrm{KA}=$ the probability of a company audited by PAF which has met earnings benchmark.

$\alpha \quad=$ Constant

AT = Audit Tenure, that is counting how long a Public Accounting Firm has a consecutive engagement with a company.

RA = Audit rotation, to find out if auditor change occurs on a company

UP = age of publication, that is adding years starting from the time when an entity is registered to IDX to the observation year.

$\beta_{1,2,3}=$ regression coefficient

$\varepsilon_{\mathrm{i}} \quad=$ Error term

A series of tests conducted on the logistic regression analysis in this study are to assess the feasibility of the regression model, test the suitability of the overall model (overall fir model), test the classification matrix, gain a regression model.

\section{Results and Discussions}

\section{An Overview of the Research Object}

Of 148 companies, the total population of the financial statements of the manufacturing companies listed on the IDX in the period 2014 - 2017, 57 companies have met the criteria and were selected to be the research sample. The criteria of financial statements used in this research are stated in Table 1. 
Table 1. The Sampling Criteria

\begin{tabular}{clc}
\hline No. & \multicolumn{1}{c}{ Information } & \multicolumn{1}{c}{$2014-2017$} \\
\hline 1 & $\begin{array}{l}\text { Manufacturing companies listed on the IDX in the period 2014- } \\
\text { 2017. }\end{array}$ \\
2 & $\begin{array}{l}\text { The companies that did not publish annual financial statements on } \\
\text { official company or IDX websites during the period 2014-2017. } \\
\text { The companies that did not perform financial statements audit, and } \\
\text { not include names of PAF and auditor in their financial statements } \\
\text { in the period 2014-2017. }\end{array}$ \\
4 & $\begin{array}{l}\text { The companies that used a currency other than Rupiah. } \\
\text { The companies that were delisted from the IDX during the period }\end{array}$ \\
6 & $\begin{array}{l}\text { 2014-2017. } \\
\text { The companies that performed sector switching during the } \\
\text { observation year 2014-2017. }\end{array}$ \\
7 & $\begin{array}{l}\text { The companies that had a negative value of Return of Asset and age } \\
\text { of publication under } 2 \text { years. }\end{array}$ \\
$\quad \begin{array}{l}\text { Total sample companies } \\
\text { Total research sample (57 companies x 4 years) }\end{array}$ & (2) \\
\hline
\end{tabular}

\section{Descriptive Statistical Analysis}

The Table below presents the results of descriptive statistical test on dependent variable - audit quality, and independent variables - audit tenure, audit rotation, and age of publication.

Table 2. Descriptive Statistical Test Results

\begin{tabular}{lccccc}
\hline & $\mathrm{n}$ & Minimum & Maximum & Mean & Std. Deviation \\
\hline Audit Quality & 228 & 0,0 & 1,0 & 0,888 & 0,3186 \\
Audit Tenture & 228 & 1,0 & 4,0 & 2,136 & 1,1122 \\
Audit Rotation & 228 & 0,0 & 1,0 & 0,588 & 0,4933 \\
Age of Publication & 228 & 2,0 & 36,0 & 20,693 & 7,9515 \\
\hline
\end{tabular}

Table 2 shows the amount of data employed in this research, that is 228 data - the total sample during the period 2014 - 2017. The test results using a statistic descriptive test on audit tenure show the engagement term held by the companies with their auditors is minimally for 1.0 year. The maximum value of audit tenure is 4.0. It indicates the engagement term for four (4) consecutive years is counted since 2014 to 2017 . The average value of audit tenure shows 2.136 years with a standard deviation of 1.1122 .

On the variable audit rotation using a dummy variable, a value of 2 comes up. The minimum value of audit rotation is 0.0 , which indicates that auditor change did not occur on the companies from the previous years, or in other words, they used the same auditors as in the previous years. The maximum value of audit rotation suggests that a value of 1.0 means the companies performed auditor change. Table 2 demonstrates the average value of audit rotation carried out by the companies is 0.588 with a standard deviation of 0.4933 .

The minimum value of publication age is counted since the date the companies were registered to the IDX or the companies launched IPO (Initial Public Offering) - the first-time selling shares to the public. Table 2 displays that the minimal age of the companies holding IPO during the observation years is 2 years and the maximum age is 36 years with an average age of publication of 20.693 years. The companies with the lowest age of publication (2 years) are PT Sekar Bumi Tbk (SKBM), PT Trisula International Tbk (TRIS), PT Wismilak Inti Makmur Tbk (WIIM), while those with the highest value of publication age is PT Merck Tbk (MERK).

\section{Test of Multicollinearity}

This test aims to examine if a correlation between independent variables is found in a logistic regression model. If the correlation is not found, the regression result is good. In a multicollinearity test, a correlation matrix between independent is used as follows. 
Table 3. Correlation Matrix

\begin{tabular}{lllll}
\hline Constant & Audit Tenure & Audit Rotation & $\begin{array}{c}\text { Age of } \\
\text { Publication }\end{array}$ \\
\hline Constant & 1,000 & $-0,228$ & $-0,131$ & $-0,871$ \\
Audit Tenure & $-0,228$ & 1,000 & $-0,023$ & $-0,198$ \\
Audit Rotation & $-0,131$ & $-0,023$ & 1,000 & $-0,33$ \\
Age of Publication & $-0,871$ & $-0,198$ & $-0,033$ & 1,000 \\
\hline
\end{tabular}

The results of multicollinearity test show that the correlation coefficient value is not found between variables more than 0.8 . To sum up, the symptoms of multicollinearity are not found between independent variables - audit tenure, audit rotation, and age of publication in this research.

\section{Logistic Regression Analysis}

Assessing feasibility of regression model

Table 4. Hosmer and Lomeshow Test

\begin{tabular}{ccc}
\hline Chi-square & df & Sig. \\
\hline 12,832 & 8 & 0,118 \\
\hline
\end{tabular}

In a test of regression model for feasibility using Hosmer and Lomeshow's Goodness of Fit Test, the results show the value of Chi-Square is 12.832 and significant 0.118 . The significance value of $0.118 \geq 0.05$ means accepting null hypothesis, or the model can predict the observation value.

\section{Testing Overall Fit Model}

Testing overall fit model was performed by comparing -2Log Likelihood (block number $=0$ ) and -2Log Likelihood (block number $=1$ ).

Table 5. Test of Overall Fit Model

\begin{tabular}{ll}
\hline Likelihood (Block Number $=0)$ & 161,820 \\
\hline Likelihood (Block Number $=1)$ & 147,623 \\
\hline
\end{tabular}

Table 5 displays that the value of initial -2LL is 161.820 and the value of end $-2 \mathrm{LL}$ is 147.623 , which means the 3 additional independent variables included in the logistic regression model fix the model fit and it shows a better regression model. This has been proven from the decreased initial -2LL which is 161.820 to be the end -2LL which is 147.623 .

\section{Obtaining Regression Model}

Model of logistic regression can be formed from parameter value in Variables in The Equation. The regression model formed is based on the value of parameter estimates in Table 6 .

Table 6. Variables in the Equation

\begin{tabular}{lcccccc}
\hline & B & S.E. & Wald & df & Sig. & Exp(B) \\
\hline Audit Tenure & 0,303 & 0,340 & 0,793 & 1 & 0,043 & 1,353 \\
Audit Rotation & 0,289 & 0,745 & 0,151 & 1 & 0,004 & 1,336 \\
Age of Publication & $-0,127$ & 0,039 & 10,767 & 1 & 0,001 & 0,881 \\
Constant & 4,698 & 1,007 & 21,750 & 1 & 0,000 & 109,767 \\
\hline
\end{tabular}

Based on the Table 6, the equation of logistic regression in this research is as follows:

$$
\text { Audit Quality }=4.698+0.303 \mathrm{X}_{1}+0.289 \mathrm{X}_{2}-0.127 \mathrm{X}_{3}+\mathrm{e}
$$

The results of logistic regression equation reveal that the regression coefficient of the variable audit tenure $\left(\mathrm{X}_{1}\right)$ is 0.30 , which indicates that every rise of one unit for the variable audit tenure, it will increase audit quality by 0.303. The regression coefficient of the variable audit rotation $\left(X_{2}\right)$ is 0.289 which indicates that every rise of one 
unit for the variable audit rotation will increase audit quality by 0.289 . The regression coefficient of the variable publication age $\left(\mathrm{X}_{3}\right)$ is -0.127 which indicates that every rise of one unit for the variable publication age will decrease audit quality by -0.127 . Table 7 presents the results of hypothesis test.

Table 7. Results of Hypotheses Test

\begin{tabular}{clccc}
\hline Hypotheses & \multicolumn{1}{c}{ Statements } & B & Sig. & Result \\
\hline $\mathrm{H}_{1}$ & $\begin{array}{l}\text { Audit tenure has a positive } \\
\text { influence on audit quality }\end{array}$ & 0,303 & 0,043 & $\begin{array}{c}\text { Hypothesis } \\
\text { supported }\end{array}$ \\
& $\begin{array}{l}\text { Audit rotation has a } \\
\text { positive influence on audit } \\
\text { quality }\end{array}$ & 0,289 & 0,004 & $\begin{array}{c}\text { Hypothesis } \\
\text { supported }\end{array}$ \\
$\mathrm{H}_{2}$ & $\begin{array}{l}\text { Age of publication has a } \\
\text { positive influence on audit } \\
\text { quality }\end{array}$ & $-0,127$ & 0,001 & $\begin{array}{c}\text { Hypothesis } \\
\text { rejected }\end{array}$ \\
\hline
\end{tabular}

\section{The Influence of Audit Tenure on Audit Quality}

If an auditor audits a company for a few years, the auditor can design an effective auditor program for the company, so that it can enhance the quality of the audit. This is in line with studies by Ardani (2017), Nugrahanti and Darsono (2014) which revealed that longer audit engagement term with the client can improve the auditors' knowledge of the client company.

In relation to audit quality, independence and objectivity of an auditor in auditing a company's financial statements can be maintained by audit rotation performed by the company, since it can prevent proximity between the auditor and managers. In turn, it will increase the audit quality. This premise is aligned with Kurniasih and Rohman (2014) revealing that audit rotation can improve audit quality.

Regarding age of publication, this variable does not necessarily guarantee that older companies have better quality than the younger companies. Thus, age of publication is not appropriate to be used as a benchmark to produce good audit quality. This is due to delisting system that applies in the IDX. The companies that have been long listed and then delisted from the IDX, they may register themselves again. This makes the companies are seen as the newly joined the Stock Exchange companies. This finding is consistent with studies by Paramita and Latrini (2015), as well as Pramaswardana and Astika (2015).

\section{Conclusion}

This research study shows that audit tenure has a positive and significant influence on audit quality. This finding corroborates Ardani (2017), Nugrahanti and Darsono (2014) revealing that longer audit tenure enables public accountants to know more the organization's conditions and have sufficient knowledge of the organization, which in turn an effective audit program can be designed for producing quality audit. In addition, audit rotation has been proven to have a positive and significant influence on audit quality. This is aligned with a study by Kurniasih and Rohman (2014) revealing that audit rotation obviously enables an auditor to be more objective in auditing an organization. By independence, an audit can have a better quality. For the variable age of publication, it has been proven that it has a negative and significant influence on audit quality due to delisting and redelisting system in the IDX. So, those that have been delisted from the IDX can register again to the IDX. Consequently, this makes them look like the newly-joined the IDX corporations; in fact, they are long-established ones with good financial records.

This research study has a few limitations which open opportunities for further research. It does not provide the criteria for the duration of an effective audit rotation. Thus, audit rotation performed should be accompanied with an auditor's competence in order to be able to produce a more quality audit.

\section{References}

Al-Thuneibat, A. A., Issa, R. T. I. Al, \& Baker, R. A. A. (2011). Do audit tenure and firm size contribute to audit quality. Managerial Auditing Journal, 26(4), 317-334.

Anthony, R. N., \& Govindarajan, V. (2007). Management Control Systems (12th ed.). Boston: McGraw-Hill Education. 
Ardani, S. V. (2017). Pengaruh tenure audit, rotasi audit, audit fee terhadap kualitas audit dengan komite audit sebagai variabel moderasi. Jurnal Akuntansi, 6(1), 1-12.

Bawono, I. R., \& Singgih, E. M. (2010). Faktor-faktor dalam diri auditor dan kualitas audit: studi pada kap "Big Four" di Indonesia. Jurnal Akuntansi Dan Auditing Indonesia, 14(2), 1-20.

Fernando, G. D., Abdel-Meguid, A. M., \& Elder, R. J. (2010). Audit quality attributes, client size and cost of equity capital. Review of Accounting and Finance, 9(4), 363-381.

Herianti, E., \& Suryani, A. (2016). Pengaruh kualitas auditor, audit delay, dan audit tenure terhadap kualitas audit perbankan yang terdaftar di bei periode 2012-2014. In Indonesian conference on management, politics, Accounting, and Communication (pp. 416-425). Jakarta: Universitas Bakrie.

Intakhan, P., \& Ussahawanitchakit, P. (2010). Roles of audit experience and ethical reasoning on audit professionalism and audit effectiveness through a moderator of stakeholder pressure: An empirical study of tax auditors in Thailand. Journal of Academy of Business and Economics, 10(5), 1-15.

Junaidi, \& Hartono, J. (2010). Non-financial factors in the going concern opinion. Journal of Indonesian Economy and Business, 25(3), 368-378.

Kurniasih, M., \& Rohman, A. (2014). Pengaruh fee audit, audit tenure, dan audit rotation terhadap kualitas audit. Diponegoro Journal of Accounting, 3(3), 1-10.

Nugrahanti, Y., \& Darsono. (2014). Pengaruh audit tenure, spesialisasi kantor akuntan publik dan ukuran perusahaan terhadap kualitas audit. Journal of Accounting, 3(3), 1-9.

Paramita, N. K. A., \& Latrini, N. M. Y. (2015). Pengaruh ukuran perusahaan, umur publikasi, masa perikatan, pergantian manajemen pada kualitas audit. E-Jurnal Akuntansi Universitas Udayana, 13(1), 142-156.

Pemerintah Indonesia. 2015. Peraturan Pemerintah No. 20 Tahun 2015 Tentang PRAKTIK Akuntan Publik. Sekretariat Negara. Jakarta

Pramaswardana, I. G. N. I., \& Astika, I. B. P. (2015). pengaruh audit tenure, audit fee, audit rotationor, spesialisasi auditor, dan umur publikasi pada kualitas audit. E-Jurnal Akuntansi Universitas Udayana, 19(1), 168-194.

Siregar, S. V., Amarullah, F., Wibowo, A., \& Anggraita, V. (2012). Audit tenure, auditor rotation, and audit quality: The case of Indonesia. Asian Journal of Business and Accounting, 5(1), 55-74.

Suciana, M. F., \& Setiawan, M. A. (2018). Pengaruh rotasi audit, spesialisasi industri kap , dan client importance terhadap kualitas audit ( studi dengan pendekatan earning surprise benchmark ). Jurnal Wahana Riset Akuntansi, 6(1), 1159-1172.

Ulum, I., Ghozali, I., \& Chariri, A. (2008). Intellectual capital dan kinerja keuangan perusahaan; Suatu analisis dengan pendekatan Partial Least Squares (PLS). In Simposium Nasional Akuntansi XI (pp. 1-31). Pontianak: Ikatan Akuntan Indonesia Kompartemen Akuntan Pendidik (IAI KAPd).

Velte, P., \& Stiglbauer, M. (2012). Impact of auditor and audit firm rotation on acounting and audit quality: A critical analysis of the EC regulation draft. Journal of Governance and Regulation, 1(3), 7-13. 